\title{
IMPLIKASI PERLINDUNGAN INDIKASI GEOGRAFIS BERDASARKAN UNDANG-UNDANG NOMOR 20 TAHUN 2016 TERHADAP PENGEMBANGAN EKONOMI LOKAL
}

\author{
Sudjana \\ Fakultas Hukum Universitas Padjadjaran \\ email: sdjana@yahoo.com
}

disampaikan 29/5/18 - di-review 2/6/18 - diterima 24/6/18

DOI: $10.25123 /$ vej.2915

\begin{abstract}
This study discusses, on the basis of analysis of Law No. 20 of 2016, the potential impact of Geographical Indication protection to local economy. By tracing other relevant laws and regulations, using in depth analysis of existing literature and other relevant qualitative data on the subject matter, the author argues that: (1) Law No. 20 of 2016 compared to the Law it replaces it more sufficient to provide protection and legal certainty to Geographical Indication beneficiaries; (2) Quite a number of potential Geographical Indications exist in Indonesia which deserve protection, especially in relation to its potential to support local economic development.
\end{abstract}

Keywords:

Geographical Indication, local economic development, legal certainty

\begin{abstract}
Abtrak
Kajian ini mendiskusikan, atas dasar analisis Undang-Undang No. 20 tahun 2016, dampak potensial perlindungan Indikasi Geografis terhadap pengembangan ekonomi local atau daerah. Dengan menelusuri aturan-aturan perundang-undangan lain yang relevan, dan menggunakan analisis mendalam terhadap pustaka dan data kualitatif lain yang terkait perihal perlindungan Indikasi Geografis, ditemukan bahwa: (1) Undang-Undang No. 20 tahun 2016, dibandingkan peraturan perundang-undangan yang digantikannya, jauh lebih memadai dalam memberikan kepastian dan perlindungan hukum pada pemegang hak atas Indikasi Geografis; (2) Ditemukan adanya sejumlah calon Indikasi Geografis tersebar di seluruh Indonesia yang seharusnya dapat didaftarkan dalam rangka mendorong pengembangan ekonomi local.
\end{abstract}

Kata kunci:

Indikasi Geografis, pengembangan ekonomi lokal, kepastian hukum

\section{Pendahuluan}

Pengaruh globalisasi di segala bidang kehidupan masyarakat, baik di bidang sosial, ekonomi, maupun budaya semakin mendorong laju perkembangan perekonomian masyarakat. Di samping itu, dengan semakin meningkatnya perkembangan tekNomorlogi informasi dan sarana transportasi, telah menjadikan kegiatan di sektor perdagangan baik barang maupun jasa mengalami 
perkembangan yang sangat pesat. Kecenderungan akan meningkatnya arus perdagangan barang dan jasa tersebut akan terus berlangsung secara terus menerus sejalan dengan pertumbuhan ekonomi nasional yang semakin meningkat. Dengan memperhatikan kenyataan dan kecenderungan seperti itu, menjadi hal yang dapat dipahami jika ada tuntutan kebutuhan suatu pengaturan yang lebih memadai dalam rangka terciptanya suatu kepastian dan peRlindungan hukum yang kuat. Apalagi beberapa negara semakin mengandalkan kegiatan ekonomi dan perdagangannya pada produk yang dihasilkan atas dasar kemampuan intelektualitas manusia. ${ }^{1}$ Di samping itu pula, keikutsertaan Indonesia meratifikasi Konvensi tentang Pembentukan Organisasi Perdagangan Dunia (World Trade Organization) yang mencakup pula persetujuan tentang Aspek-aspek Dagang dari Kekayaan Intelektual (Trade Related Aspect of Intellectual Property Rights/TRIPs). ${ }^{2}$

Pada tahun 2016, pemerintah Indonesia mengesahkan Undang-Undang Nomor 20 Tahun 2016 Tentang Merek dan Indikasi Geografis yang menggantikan Undang-Undang Nomor 15 Tahun 2001 Tentang Merek. Penambahan judul Undang-Undang tersebut yang semula “ .... Tentang Merek” dengan “.... Tentang Merek dan indikasi Geografis" memiliki dasar pertimbangan sebagaimana dijelaskan dalam Bagian Menimbang poin a, b, dan c Undang-Undang tersebut ${ }^{3}$

${ }^{1}$ Undang-Undang RI No 20 Tahun 2016 Tentang Merek dan Indikasi Geografis, LN RI Tahun 2016 No. 252, Penjelasan Umum.

${ }^{2}$ Sebagaimana telah disahkan dengan Undang-Undang Nomor 7 Tahun 1994 Tentang Pengesahan Agreement Establishing the World Trade Organization (Persetujuan Pembentukan Organisasi Perdagangan Dunia), telah menuntut Indonesia untuk mematuhi dan melaksanakan isi dari perjanjian internasional tersebut. Ratifikasi dari peraturan tersebut mendorong keikutsertaan Indonesia dalam meratifikasi Paris Convention for the Protection of Industrial Property (Konvensi Paris) yang telah disahkan dengan Keputusan Presiden Nomor 15 Tahun 1997 dan Trademark Law Treaty (Traktat Hukum Merek) yang disahkan dengan Keputusan Presiden Nomor 17 Tahun 1997.

${ }^{3}$ a. bahwa di dalam era perdagangan global, sejalan dengan konvensi internasional yang telah diratifikasi Indonesia, peranan Merek dan Indikasi Geografis menjadi sangat penting terutama dalam menjaga persaingan usaha yang sehat, berkeadilan, pelindungan konsumen, serta pelindungan Usaha Mikro, Kecil, dan Menengah dan industri dalam negeri; b. bahwa untuk lebih meningkatkan pelayanan dan memberikan kepastian hukum bagi dunia industri, perdagangan, dan investasi dalam menghadapi perkembangan perekonomian lokal, nasional, regional, dan internasional serta perkembangan teknologi informasi dan komunikasi, perlu didukung oleh 
Sejalan dengan globalisasi ekonomi yang berarti terintegrasinya ekonomi berbagai negara menjadi satu seolah-olah tanpa dibatasi oleh kedaulatan negara. Salah satu ciri yang paling dominan pada globalisasi ekonomi adalah sifat bergerak yang cepat, baik dalam transaksi maupun pergerakan arus barang dan modal. Hal ini mempengaruhi pula berbagai peraturan di bidang bisnis yang cepat pula mengalami perubahan. ${ }^{4}$ Christophe Bellmann dan Graham Dutfield, berpendapat banyak tantangan yang harus dihadapi bagi negara-negara berkembang untuk melakukan desisgning dan mengimplementasikan kebijakan kekayaan intelektual (selanjutnya disebut KI) dalam tingkat nasional dan Internasional. 5

Dengan demikian, perlindungan hukum terhadap berbagai macam produk yang mencirikan Indikasi Geografis (selanjutnya disebut IG) di Indonesia harus dapat menjawab tantangan global (perdagangan bertaraf internasional) yakni dengan memberikan aturan hukum yang memadai sehingga dapat memberikan kepastian hukum terhadap produk asli Indonesia di luar negeri. ${ }^{6}$ Kepastian hukum tersebut berkaitan dengan substansi tentang pengaturan Indikasi Geografis yang

suatu peraturan perundang-undangan di bidang Merek dan Indikasi Geografis yang lebih memadai; c. bahwa dalam Undang-Undang Nomor 15 Tahun 2001 Tentang Merek masih terdapat kekurangan dan belum dapat menampung perkembangan kebutuhan masyarakat di bidang Merek dan Indikasi Geografis serta belum cukup menjamin pelindungan potensi ekonomi lokal dan nasional sehingga perlu diganti.

4 Aristeus, Syprianus, "Peluang Industri dan Perdagangan Indonesia Dalam Pelaksanaan Masyarakat Ekonomi ASEAN (Industry and Trade Opportunity of Indonesia on ASEAN Economic Community), Media Pembinaan Hukum Nasional,. Jurnal Rechtsvinding 2014, 3(2): 146 sebagaimana dikutip oleh Tomy Pasca Rifai, Kesiapan Undang-Undang Nomor 20 Tahun 2016 Tentang Merek Dan Indikasi Geografis Dalam Menghadapi Masyarakat Ekonomi ASEAN, Faculty of Law, Lampung University, Jurnal Fiat Justitia, volume 10 issue 4 October-December 2016: hlm. 587-814.

${ }^{5}$ Christophe Bellmann, Graham Dutfield \& Melendez-Ortiz, Trading in Knowledge : Development Perspectives on TRIPS, Trade and Sustainability, International Centre for Trade and Sustainable Development (ICTSD), Earthscan, London, 2003, hlm 1 sebagaimana dikutip oleh I Gede Agus Kurniawan, Pengaturan Penghentian Pemakaian Indikasi Geografis Pada Merek Terdaftar OLeh Pihak Lain Yang Tidak Berhak (Studi Komparatif Beberapa Negara), Tesis, Program Magister Program Studi Ilmu Hukum Program Pasca Sarjana Universitas Udayana Denpasar, 2013, hlm 5.

6 Indra Rahmatullah, Perlindungan Indikasi Geografis Dalam Hak Kekayaan Intelektual (HKI) Melalui Ratifikasi Perjanjian Lisabon, wordpress.com/2013/10/25/perlindungan-indikasigeografis-dalam-hakkekayaan-intelektual-hki-melalui-ratifikasi-perjanjian-lisabon/diakses tanggal 1 Desember 2017 pukul 21.00. 
memberikan jaminan perlindungan hukum bagi pemegang hak sehingga responsif terhadap pelanggaran oleh pihak lain.

Hal tersebut dibuktikan dengan adanya contoh dua kasus mengenai pelanggaran IG, yaitu kasus pelanggaran Kopi Toraja dan Kopi Gayo. Kasus pendaftaran merek Kopi dengan nama Toraja oleh Key Coffee Co. dimulai pada saat pemilik merek "Toarco Toraja" tersebut mengajukan permohonan perlindungan atas merek kopi yang mulai populer di Jepang. Ancaman adanya pesaing yang menggunakan merek dagang dengan nama yang sama menjadi dasar permohonan perlindungan mereknya pada 1974 dan kemudian pendaftarannya dikabulkan pada 1976. ${ }^{7}$ Kasus kedua, Kopi Gayo sebagai merek dagang di klaim milik sebuah perusahaan asal Belanda sebagai pemegang hak yang Nomortabene Kopi Gayo tersebut adalah khas dari Nanggroe Aceh Darussalam. Perusahaan asal Belanda tersebut (Holland Coffe B.V) mengklaim bahwa perusahaan tersebut merupakan pemilik dari hak merek dagang kopi tersebut dan terdaftar di dunia internasional dengan nama Gayo Mountain Coffee. ${ }^{8}$

Tuntutan adanya perlindungan terhadap IG dalam sistem hukum KI adalah upaya untuk melindungi produk-produk masyarakat lokal dalam negeri karena merek yang dipakai oleh pelaku bisnis untuk memperkenalkan produk, biasanya menggunakan nama tempat atau lokasi geografis yang menjelaskan dari mana barang tersebut berasal. Namun demikian, Indonesia belum memiliki instrumen yang mengatur IG sebagai komponen KI.9 Alfons mengemukakan, dalam faktor substansi hukum, IG tidak dicantumkan dalam ketentuan umum Undang-Undang Merek Nomor 15 Tahun 2001 dan Peraturan Pemerintah Nomor 51 Tahun 2007. Hal ini menunjukkan bahwa substansi hukum di bidang IG tidak memadai, karena itu beralasan apabila kemudian disahkan Undang-Undang Nomor 20 Tahun 2016

7 Eddy Damian, dkk. Hak Kekayaan Intelektual Suatu Pengantar, Alumni, Bandung, 2002, hlm 15.

8 Surip Mawardi, "Establishment of Geographical Indication Protection System in Indonesia, Case in Coffee," Worldwide Symposium on Geographical Indications jointly orginized by the World Intellectual Property Organization (WIPO) and the Patent Office of the Republic of Bulgaria, Sofia, June 10 - 12, 2009, hlm 11 sebagaimana dikutip oleh Indra Rahmatullah, Supra no 4.

9 Andy Noorsaman Sommeng dan Agung Damar Sasongko, Indikasi Geografis: Sebuah Pengantar, Direktorat Jenderal HKI (DJHKI), Jakarta 2008, hlm 19. 
untuk mengubah Undang-Undang Nomor 15 Tahun 2001. Selain itu, faktor struktur juga sangat berpengaruh terhadap pendaftaran IG oleh masyarakat. Hal ini disebabkan karena para pejabat yang terkait di bidang tersebut belum melakukan sosialisasi yang optimal dan ini berakibat pada faktor kultur yaitu masyarakat tidak melakukan pendaftaran terhadap IG karena tidak mengetahui konsep IG tersebut. ${ }^{10}$ Berdasarkan hal itu, didapati masalah kepastian hukum tentang IG yang menyangkut aspek budaya hukum, di samping aspek pengaturan Nomorrma hukum yang disebut sebelumnya. Persoalan budaya hukum seperti itu memang tidak mungkin dilepaskan dari konteks pembangunan sistem hukum nasional yang, dalam kaitannya dengan kepentingan IG, terkait erat dengan penguatan arus globalisasi ekonomi. ${ }^{11}$

Lahirnya Undang-Undang Nomor 20 Tahun 2016 sebagai implementasi dari ketentuan internasional mengatur IG secara lebih komprehensif daripada Undang-Undang Nomor 15 Tahun 2001 diharapkan dapat memberikan kepastian hukum dalam mengembangkan potensi IG yang bernilai ekonomi tinggi, sehingga Undang-Undang tersebut diharapkan memiliki implikasi positif terhadap pengembangan ekonomi lokal dan mendorong kesadaran masyarakat (Pemda) untuk mendaftarkannya. Oleh karena itu, permasalahan yang akan dikaji adalah (1) Bagaimana pengaturan IG secara internasional dan nasional; (2) Bagaimana Implikasi Perlindungan IG berdasarkan Undang-Undang Nomor 20 Tahun 2016 terhadap Pengembangan Ekonomi Lokal?; (3) Bagaimana meningkatkan potensi ekonomi lokal dari masyarakat (dan Pemda) melalui pendaftaran indikasi geografis di Indonesia?

\footnotetext{
${ }^{10}$ https://prasetya.ub.ac.id/berita/Melindungi-HAKI-Produk-Lokal-dengan-ImplementasiIndikasi-Geografis-1661-id.html diakses diaskes 13 Desember 2017 pukul 21.00 sebagaimana juga dikutip oleh Puji Tri Nuzzuli, Pendaftaran Indikasi Geografis Atas Barang-Barang Hasil Pertanian/Perkebunan Di Aceh tersedia dalam https://media.neliti.com/media/publications/14028-ID-pendaftaran-indikasi-geografis-atasbarang-barang-hasil-pertanianperkebunan-di-a.pdf diaskes 13 Desember 2017 pukul 22.00.

${ }^{11}$ Sunaryati Hartono, Membangun Budaya Hukum Pancasila sebagai Bagian dari Sistem Hukum Nasional Indonesia di Abad 21, 1 Veritas et Justitia 258, 2015.
} 


\section{Pembahasan}

\section{Pengaturan IG secara Internasional dan Nasional}

The Paris Convention for the Protection of Industrial Property 1883 (Konvensi Paris 1883), mengatur tentang Appellation of Origin (AO) sebagai berikut:

"... the geographical name of a country, region, or locality, which serves to designate a product originating therein, the quality and characteristic of which are due exclusively or essentially to the geographical environment, including natural and human factor."

Bersama dengan Indikasi Asal (Indication of Source), AO termasuk dalam aturan nama dagang yang memakai nama tempat untuk produk dagangnya. Nama tempat berfungsi sebagai tanda pembeda. Lebih luas pengertiannya dari AO yang harus sama persis dengan produknya, IG merujuk tidak hanya pada nama tempat, tetapi juga tanda-tanda kedaerahan atau lambang dari lokasi bersangkutan yang mengidentifikasikan asal produk khas bersangkutan. ${ }^{12}$

Ketentuan Pasal IX: 6 GATT $1947^{13}$ tidak diberlakukan sebagai ketentuan hukum yang mengikat dan ditetapkan sebagai syarat wajib yang diberlakukan, tetapi ketentuan tersebut lebih cenderung ditetapkan sebagai kerjasama antar negara anggota untuk menangkal terjadinya penyesatan. Juga kewajiban antar negara anggota untuk melaksanakan kerjasama dalam merumuskan kertentuan

12 Contohnya seperti Menara Petronas, Opera House Sidney ataupun Rumah Adat Toraja. Tanda itu bukan produk dagangnya, tetapi melekat pada produk sebagai tanda asal yang berhubungan dengan kerakteristik produknya. Bandingkan kondisinya dengan produk berupa Champagne, Tequila, ataupun keju Parmagiano http://www.hukumonline.com/ klinik/detail/ lt4fd1bd073c3a6/indikasi-geografis diakses 26 Desember 2017 pukul 21.00.

13 The GATT 1947 Pasal IX :6 konsep perlindungan indikasi geografis: "The contracting parties shall co-operate each other with a view to preventing the use of trade names in such manners as to misrepresent the true origin of a product, to determent of such distinctive regional or geographical names of products of territory of a contracting party as are propected by its legislation. Each contracting party shall acoord full and sympathetic consideration to such requests or representations as may be made by any other contracting party regarding the application of the undertaking set forth in preceding sentence to names of products which have been communicate to it by the other contracting party." 
hukum dalam peraturan hukumnya masing-masing terhadap perlindungan nama geografis. ${ }^{14}$

Perjanjian Lisabon 1958 menjelaskan Appellation of Origin sebagai berikut:

"In this Agreement, "appellation of origin" means the geographical deNomormination of a country, region, or locality, which serves to designate a product originating therein, the quality or characteristics of which are due exclusively or essentially to the geographical environment, including natural and human factors."15

Perjanjian Lisabon bertujuan dalam rangka merespon kebutuhan hukum internasional dan memfasilitasi dalam hal perlindungan terhadap IG seperti Appellation of Origin di beberapa negara selain negara asal indikasi geografis tersebut melalui sistem single registration di Biro Internasional WIP0. ${ }^{16}$

Pada tahun 1974 dan 1975 WIPO berinisiatif menyelenggarakan persidangan untuk dibentuknya suatu perjanjian internasional dengan merevisi ketentuan terkait dengan IG dalam Konvensi Paris sehingga menjadi perjanjian internasional yang baru. ${ }^{17}$ Sebagai bagian dalam taraf negoisasi dalam rangka

${ }^{14}$ Saky Septiono, Perlindungan Indikasi Geografis dan Potensi Indikasi Geografis Indonesia tersedia dalam http://kemal-assegaf.blogspot.co.id/2011/12/indikasi-geografi.html diakses 26 Desember 2017 pukul 21.00.

${ }^{15}$ Lisbon Agreement for the Protection of Appellations of Origin and their International Registrationn of October 31, 1958, as revised at Stockholm on July 14, 1967, and as amended on September 28, 1979.

16 Tujuan utama pendaftaran tersebut merupakan sebagai dasar pemikiran atau alasan dibuatnya sistem registrasi Internasional. Sebagaimana diketahui bahwa perlindungan terhadap IG di beberapa negara menjadi sesuatu yang complicated dikarenakan terdapat beberapa perbedaan konsep hukum yang sudah ada di berbagai negara (termasuk perbedaan tradisi hukum nasional) di dalam sebuah framework baik secara historis maupun kondisi ekonomi negara tersebut. Perjanjian Lisabon dibuat pada tahun 1958 dan diperbaiki di Stockholm pada tahun 1967. Pemberlakuan persetujuan ini dilaksanakan pada tanggal 26 September tahun 1966 yang diadministrasikan oleh Biro Internasional WIPO. Perjanjian ini berisi tentang perlindungan terhadap Sebutan Asal (Appellation of Origin) dan sistem registrasi Internasional. Indra Rahmatullah, Supra No 4.

17 WIPO Standing Commiitee on the Law of Trademarks, Industrial Designs and Geographical Indication, SCT/8/4, April 2, 2002 at paras, 66-71 diakses 27 Desember 2017 pukul 22.00. Selajutnya Berdasarkan laporan WIPO international bureau pendekatan yang dipandang dalam perlindungan IG berdasar pada empat katagori pertimbangan hukum yaitu : (1) unfair competition and passing of, (2) collective and certification mark, (3) protected appellations of 
merevisi Konvensi Paris pada tahun 1980. Awal tahun 1990, negara anggota mempertimbangkan untuk mengadopsi ketentuan tambahan (additional articles)1018 quater addressing geographical indications.

Ketentuan tentang Appellation of Origin dalam Konvensi Paris dikembangkan melalui Perjanjian TRIPs (TRIPs Agreement) sebagai IG (Geographical Indication).

Article 22 TRIPs Agreement mengatakan bahwa:

"Geographical indications are for the purposes of this agreement, indications which indentify a good as originating in the territory of a member, or a region or locality in that territory, where a given quality, reputation or other characteristics of the good is essentially attributable to its geographical origin." 19

Sesuai dengan standar minimum yang dianut dalam Perjanjian TRIPs, maka pengaturan IG diserahkan pada masing-masing Negara peserta, apakah bersifat "suigeneris" (tersendiri) atau diatur bersama dengan merek meskipun TRIPs mengakui bahwa merek dan Indikasi geografis merupakan rezim KI yang berbeda.

TRIPs menyatakan "for the purpose of this agreement" berarti, unsur-unsur definisi IG merupakan sifat khas yang berbeda dengan rezim KI lain. Setidaknya, ada empat unsur pokok IG dalam Perjanjian TRIPs, yaitu, pertama, unsur nama geografis untuk mengidentifikasi, tidak bersifat mutlak karena dapat menggunakan nama Nomorn-geografis; kedua, unsur wilayah dalam negara sebagai tempat produksi tidak identik dengan wilayah administratif namun disesuaikan dengan kondisi faktual; ketiga, unsur kepemilikan dalam IG bukan

origin and registered geographical indications dan (4) administratives schemes for protection. Lihat SCT/8/4, April 2, 2002, id.

${ }^{18}$ Mahkamah Agung RI, GATT, TRIPS Dan Kekayaan Intelektual, 1998. hlm 70.

19 TRIPs memberikan definisi IG sebagai tanda yang mengidentifikasikan suatu wilayah negara anggota, atau kawasan atau daerah di dalam wilayah tersebut sebagai asal barang, di mana reputasi, kualitas dan karakteristik barang yang bersangkutan sangat ditentukan oleh faktor geografis. Dengan demikian, asal suatu barang tertentu yang melekat dengan reputasi, karakteristik dan kualitas suatu barang yang dikaitkan dengan wilayah tertentu dilindungi secara yuridis. Lihat OK. Saidin, Aspek Hukum Hak Kekayaan Intelektual (Intellectual Property Rights,) Raja Grafindo, Jakarta, 2004, hlm. 386. 
merupakan hak individual (private right) tetapi hak komunal (communal right), maka IG merupakan hak untuk menggunakan (right to use); dan keempat, unsur kualitas, reputasi, atau karakteristik lain yang bersifat alternatif, sehingga barang sudah cukup memenuhi salah satu dari unsur tersebut. ${ }^{20}$

Perjanjian Madrid atau Madrid Agreement Concerning The International Registration of Marks yang ditandatangani tahun 1981, dalam Pasal 1 mengatakan:

"All goods bearings a false or deceptive by wich one of the countries to wich this agreement applies or a place situated therein, is directly indicated as being the country or palce of origin hsall be seized in importation into any of the said countries."

Ketentuan ini sebenarnya telah memberikan perlindungan informasi yang menyesatkan darimana barang tersebut berasal. Namun dalam perjanjian ini tidak secara spesifik mengatur konsep IG. Perjanjian ini hanya mengatur terhadap adanya keharusan untuk menyita setiap barang IG yang salah atau menyesatkan. Bahkan menurut Zen Umar Purba, perjanjian ini tidak menambah level atau keterangan tentang perlindungan Indikasi Asal sebagaimana yang telah diatur di dalam Konvensi Paris. ${ }^{21}$

Pengaturan terkait IG sangat beragam di berbagai Negara, ${ }^{22}$ tetapi Indonesia memilih digabungkan bersama-sama dengan merek sebagaimana

\footnotetext{
${ }^{20}$ Wahyu Sasongko, Indikasi Geografis: Rezim HKI Yang Bersifat Sui Generis, Jurnal Media Hukum, http://download.portalgaruda.org/article.php?article=98312\&val= 648, diakses 10 Desember 2017, 2008, hlm. 107-108

${ }^{21}$ Indra Rahmatullah, Supra no 4.

${ }^{22}$ Amerika Serikat mengatur dalam UU Merek, Peraturan ATF \& Hukum Kebiasaan; Uni Eropa berdasarkan Peraturan Komunitas Eropa (EEC No.2081/92); Australia mengatur melalui The Wine dan Brandy Australia Act 1980 (AWBC), Trade Practice Act 1995, UU Merek 1995; India dalam The Act of Geographical Indications of Goods (Registration \& Protection)No. 48 of 1999, Singapura : Geographical Indications Act 44 of 1998, Trade Marks Act (Cap. 332, 2005 Rev. Ed.), Indonesia: UU Merek,Vietnam : Intellectual Property Law (Law No. 50-2005-QH11), Latvia: Law on Trademarks and Indications of Geographical Origin 8 February2007,Ghana : Trade Marks Act, 2004 (Act 664) - Geographical Indications Act 2003 (Act 659) --Act on Protection against Unfair Competition No. 589 of 2000I Gede Agus Kurniawan, Pengaturan Penghentian Pemakaian Indikasi Geografis Pada Merek Terdaftar Oleh Pihak Lain Yang Tidak Berhak (Studi Komparatif Beberapa Negara), Program Studi Ilmu Hukum Pasca Sarjana Universitas Udayana Denpasar, 2013, hlm 9 tersedia dalam file:///C:/Users/kiki/Downloads/5940-1-9569-1-10-20130715.pdf diakses 26 Desember 2017 pukul 20.00.
} 
tertuang dalam Undang-Undang Nomor 15 Tahun 2001 Tentang Merek tetapi pengaturan tersebut bersifat sumir sehingga ketentuan lebih lanjut diatur dalam Peraturan Pemerintah Nomor 51 Tahun 2007. IG diatur lebih lengkap setelah pemerintah mengganti Undang-Undang Nomor 15 Tahun 2001 dengan UndangUndang Nomor 20 Tahun 2016 Tentang Merek dan IG. ${ }^{23}$

\section{a. Definisi}

Ketentuan Umum Undang-Undang Nomor 15 Tahun 2001 tidak memberikan definisi tentang IG tetapi menyebutkan kriterianya yaitu "IG dilindungi sebagai suatu tanda yang menunjukan daerah asal suatu barang, yang karena faktor lingkungan geografis termasuk faktor alam, faktor manusia atau kombinasi dari kedua faktor tersebut, memberikan ciri dan kualitas tertentu pada barang yang dihasilkan." Sedangkan Undang-Undang Nomor 20 Tahun 2016, secara tegas memberikan definisi, meskipun definisi tersebut pada dasarnya hampir sama dengan kriteria IG dalam Undang-Undang Nomor 15 Tahun 2001. Pasal 1 Angka 6 Undang-Undang Nomor 20 Tahun 2016 mengatakan“IG adalah suatu tanda yang menunjukkan daerah asal suatu barang dan/atau produk yang karena faktor lingkungan geografis termasuk faktor alam, faktor manusia atau kombinasi dari kedua faktor tersebut memberikan reputasi, kualitas, dan karakteristik tertentu pada barang dan/atau produk yang dihasilkan."

Obyek IG seharusnya dibatasi pada hasil alam karena disebut sebagai IG jika keunikan, keistimewaan, atau keunggulan dari produk tersebut dibandingkan dengan produk sejenis lain lahir dari bumi (geo) tempat produk tersebut berasal. Jika yang hendak ditonjolkan adalah manusianya, maka " $f o l k$ " adalah kata yang lebih tepat. ${ }^{24}$ Karena itu, pengaturan tentang IG harus mencerminkan hasil alam

\footnotetext{
${ }^{23}$ Indikasi Geografis diatur dalam Bab VIII , Pasal 53 sampai dengan Pasal 62 No 20 Tahun 2016.

${ }^{24}$ Brian Prastyo, http://staff.blog.ui.ac.id/brian.amy/2008/04/09/merek-dan-indikasi-geografis/ diakses 26 Desember 2017 pukul 20.00.
} 
suatu wilayah tertentu dan kualitas karateristik produk yang dihasilkan, ${ }^{25}$ sehingga mampu mengembangkan ekonomi masyarakat lokal.

\section{b. Permohonan Perlindungan Indikasi Geografis}

IG dilindungi setelah didaftarkan dengan terlebih dahulu harus mengajukan permohonan kepada Menteri. Pemohon merupakan: a. lembaga yang mewakili masyarakat di kawasan geografis tertentu yang mengusahakan suatu barang dan/atau produk berupa: 1 . sumber daya alam; 2. barang kerajinan tangan; atau 3. hasil industri. b. pemerintah daerah provinsi atau kabupaten/kota. Undang-Undang Nomor 20 Tahun 2016 memperluas pemohon perlindungan Indikasi Geografis, yaitu Pemerintah Daerah provinsi atau kabupaten/kota yang tidak diatur dalam Undang-Undang Nomor 15 Tahun 2001 tetapi Undang Undang Nomor 20 Tahun 2016 tidak mencantumkan kelompok konsumen yang mengajukan permohonan sebagaimana diatur dalam Undang-Undang Nomor 15 Tahun 2001. Adanya ketentuan Pemerintah Daerah dapat mengajukan permohonan merupakan langkah yang tepat mengingat IG merujuk daerah asal barang yang karena faktor lingkungan geografis termasuk alam, manusia atau kombinasi dari kedua faktor tersebut, memberikan ciri dan kualitas tertentu pada barang yang dihasilkan. ${ }^{26}$

Undang-Undang Nomor 20 Tahun 2016 mengatur Permohonan yang diajukan oleh pemohon yang bertempat tinggal atau berkedudukan tetap di luar wilayah NKRI wajib diajukan melalui Kuasanya di Indonesia. Permohonan tersebut hanya dapat didaftar apabila IG telah memperoleh pengakuan dari pemerintah negaranya dan/atau terdaftar sesuai dengan ketentuan yang berlaku di negara asalnya. Ketentuan tersebut tidak diatur dalam Undang-Undang Nomor

25 Bandingkan dengan Sudaryat et al, Hak Kekayaan Intelektual, Oase Media, Bandung, 2010, hlm. 178.

26 Namun, dihapuskannya pemohon adalah kelompok konsumen dalam UU No 20 tahun 2016 merupakan kebijakan yang kurang tepat karena konsumen memiliki kepentingan terhadap IG asal barang, sehingga harus mendapatkan perlindungan terhadap pihak lain yang memanipulasi asal barang, karena itu seharusnya "kelompok konsumen" harus tetap ada sehingga dapat mengajukan permohonan perlindungan. 
15 Tahun 2001, padahal dapat terjadi permohonan IG diajukan oleh pihak pemohon yang berada diluar wilayah Indonesia tetapi untuk memastikan bahwa IG yang diajukan tersebut memiliki legalitas kepemilikan, maka harus memperoleh pengakuan dari pemerintah Negara asalnya.

Undang-Undang Nomor 20 Tahun 2016 mengatur IG yang dapat didaftarkan berdasarkan perjanjian internasional. Ketentuan ini akan lebih praktis dan memudahkan secara teknis administrasi permohonan perlindungan IG di Negara-negara lain. Ketentuan tersebut tidak diatur dalam Undang-Undang Nomor 15 Tahun 2001, sehingga apabila pemohon mengajukan pendaftaran di negara-negara lain dilakukan melalui hak prioritas. ${ }^{27}$ Hak prioritas diatur juga dalam Undang-Undang Nomor 20 Tahun 2016, sehingga pengembangan ekonomi melalui IG lebih terbuka karena bagi pemohon yang akan mengajukan permohonan IG di Negara lain mempunyai pilihan atau alternatif.

\section{c. IG yang tidak dapat didaftar dan ditolak}

Permohonan IG tidak dapat didaftar jika: a. bertentangan dengan ideologi negara, peraturan perUndang-Undangan, moralitas, agama, kesusilaan, dan ketertiban umum; b. menyesatkan atau memperdaya masyarakat mengenai reputasi, kualitas, karakteristik, asal sumber, proses pembuatan barang, dan/atau kegunaannya; dan c. merupakan nama yang telah digunakan sebagai varietas tanaman dan digunakan bagi varietas tanaman yang sejenis, kecuali ada penambahan padanan kata yang menunjukkan faktor IG yang sejenis. ${ }^{28}$ Permohonan IG ditolak jika: a. Dokumen Deskripsi IG tidak dapat dibuktikan kebenarannya; dan/atau b. memiliki persamaan pada keseluruhannya dengan IG

\footnotetext{
27 Hak Prioritas adalah hak pemohon untuk mengajukan permohonan yang berasal dari negara yang tergabung dalam Paris Convention for the Protection of Industrial Property atau Agreement Establishing the World Trade Organization untuk memperoleh pengakuan bahwa tanggal penerimaan di negara asal merupakan tanggal prioritas di negara tujuan yang juga anggota salah satu dari kedua perjanjian itu selama pengajuan tersebut dilakukan dalam kurun waktu yang telah ditentukan berdasarkan Paris Convention for the Protection of Industrial Property.

28 Pasal 56 (1) UU No 20 Tahun 2016.
} 
yang sudah terdaftar. ${ }^{29}$ Norma IG yang tidak dapat didaftar yang diatur dalam Pasal 56 Undang-Undang Nomor 20 Tahun 2016 tersebut lebih luas daripada Pasal 56 Ayat (4) Undang-Undang Nomor 15 Tahun 2001, karena menambahkan dengan "nama yang digunakan sebagai varietas tanaman dan digunakan bagi varietas tanaman yang sejenis, kecuali ada penambahan padanan kata yang menunjukkan faktor IG yang sejenis.” Ketentuan ini penting karena dapat terjadi IG tersebut berbentuk "varietas tanaman, sehingga dengan dicantumkannya kalimat tersebut, pengaturannya tidak terjadi tumpang tindih ("overlapping") dengan Undang-Undang Nomor 29 Tahun 2000 yang mengatur tentang Perlindungan Varietas Tanaman. Selanjutnya, Undang-Undang Nomor 20 Tahun 2016 membedakan "frase tidak dapat didaftar" dengan "ditolak." Penulis lebih setuju dengan Undang-Undang Nomor 20 Tahun 2016 karena makna "tidak dapat didaftar" berbeda dengan "ditolak." Makna "tidak dapat didaftar" artinya tidak memenuhi secara persyaratan formal misalnya "karena bertentangan", sedangkan "ditolak" lebih pada "syarat materil”, misalnya isi Indikasi Geografis tidak dapat dibuktikan kebenarannya. Dengan demikian, ketentuan tentang IG yang tidak dapat didaftar dan ditolak dalam Undang-Undang Nomor 20 Tahun 2016 memberikan jaminan kepastian hukum dan perlindungan terhadap persaingan usaha tidak sehat, sehingga tidak menghambat pemilik IG dalam mengembangkan aktivitas ekonominya.

\section{d. Pemeriksaan Substantif}

Undang-Undang Nomor 20 Tahun 2016 mensyaratkan adanya pemeriksaan substantif yang tidak diatur dalam Undang-Undang Nomor 15 tahun 2016. Ketentuan ini penting dilihat dari aspek "kepastian hak" dalam arti pemohon IG memang pemohon yang berhak atas IG yang dimohonkan pendaftarannya dan adanya pemeriksaan substantif untuk memastikan bahwa kreasi yang diajukan memenuhi persyaratan sebagai IG (kepastian hukum)

29 Pasal 56 (2) UU No 20 Tahun 2016. 
sehingga komersialisasi terhadap IG tersebut merupakan pengembangan ekonomi yang sehat.

\section{e. Jangka Waktu Pelindungan dan Penghapusan IG}

Undang-Undang Nomor 15 Tahun 2001 tidak mengatur tentang Penghapusan IG, berbeda dengan Undang-Undang Nomor 20 Tahun 2016 sebagaimana tercantum dalam Pasal 61 yang berbunyi:

(1) IG dilindungi selama terjaganya reputasi, kualitas, dan karakteristik yang menjadi dasar diberikannya pelindungan IG pada suatu barang.

(2) IG dapat dihapus jika: a. tidak dipenuhinya ketentuan sebagaimana dimaksud pada ayat (1); dan/atau b. melanggar ketentuan sebagaimana dimaksud dalam Pasal 56 ayat (1) huruf a. ${ }^{30}$

\section{f. Pelanggaran atas IG}

Pasal 66 Undang-Undang Nomor 20 Tahun 2016 menjelaskan Pelanggaran atas IG mencakup: a. pemakaian IG, baik secara langsung maupun tidak langsung atas barang dan/atau produk yang tidak memenuhi Dokumen Deskripsi IG; b. pemakaian suatu tanda IG, baik secara langsung maupun tidak langsung atas barang dan/atau produk yang dilindungi atau tidak dilindungi dengan maksud untuk: 1. menunjukkan bahwa barang dan/atau produk tersebut sebanding kualitasnya dengan barang dan/atau produk yang dilindungi oleh IG; 2. mendapatkan keuntungan dari pemakaian tersebut; atau 3. mendapatkan keuntungan atas reputasi IG c. pemakaian IG yang dapat menyesatkan masyarakat sehubungan dengan asal-usul geografis barang itu; d. pemakaian IG oleh bukan pemakai IG terdaftar; e. peniruan atau penyalahgunaan yang dapat menyesatkan sehubungan dengan asal tempat barang dan/atau produk atau kualitas barang

30 Pasal 56 (1) Permohonan Indikasi Geografis tidak dapat didaftar jika: a. bertentangan dengan ideologi negara, peraturan perundang-undangan, moralitas, agama, kesusilaan, dan ketertiban umum;b. menyesatkan atau memperdaya masyarakat mengenai reputasi, kualitas, karakteristik, asal sumber, proses pembuatan barang, dan/atau kegunaannya; dan c. merupakan nama yang telah digunakan sebagai varietas tanaman dan digunakan bagi varietas tanaman yang sejenis, kecuali ada penambahan padanan kata yang menunjukkan faktor indikasi geografis yang sejenis. 
dan/atau produk yang terdapat pada: 1. pembungkus atau kemasan; 2. keterangan dalam iklan; 3. keterangan dalam dokumen mengenai barang dan/atau produk tersebut; atau 4. informasi yang dapat menyesatkan mengenai asal-usulnya dalam suatu kemasan. f. tindakan lainnya yang dapat menyesatkan masyarakat luas mengenai kebenaran asal barang dan/atau produk tersebut. Undang-Undang Nomor 15 Tahun 2001 tidak secara tegas menjelaskan pelanggaran atas IG, tetapi pemegang hak IG dapat mengajukan gugatan. ${ }^{31}$

\section{g. Pembinaan dan Pengawasan IG}

Undang-Undang Nomor 15 Tahun 2001 tidak mengatur tentang pembinaan dan pengawasan, tetapi Undang-Undang Nomor 20 Tahun 2016 menjelaskan: Pembinaan Indikasi Geografis ${ }^{32}$ dilakukan oleh pemerintah pusat dan/atau pemerintah daerah sesuai dengan kewenangannya. Pengawasan IG dilakukan oleh pemerintah pusat dan pemerintah daerah sesuai dengan kewenangannya tetapi pengawasan dapat pula dilakukan oleh masyarakat. Pengawasan dilakukan untuk: a. menjamin tetap adanya reputasi, kualitas, dan karakteristik yang menjadi dasar diterbitkannya IG; dan b. mencegah penggunaan IG secara tidak sah. Hasil disampaikan kepada pemegang hak IG dan/atau Menteri. Pengaturan tentang pembinaan dan pengawasan penting dari sisi manajemen perlindungan IG karena pembinaan adalah usaha, tindakan, dan kegiatan yang berupa pendidikan

31 Pasal 57 UU No 15 Tahun 2001 sebagai berikut : (1) Pemegang hak atas IG dapat mengajukan gugatan terhadap pemakai IG yang tanpa hak berupa permohonan ganti rugi dan penghentian penggunaan serta pemusnahan etiket IG yang digunakan secara tanpa hak tersebut. (2) Untuk mencegah kerugian yang lebih besar pada pihak yang haknya dilanggar, hakim dapat memerintahkan pelanggaran untuk menghentikan kegiatan pembuatan, perbanyak serta memerintahkan pemusnahkan etiket IG yang digunakan secara tanpa hak tersebut.

32 Pembinaan tersebut meliputi: a. persiapan untuk pemenuhan persyaratan Permohonan IG; b.Permohonan pendaftaran IG; c. pemanfaatan dan komersialisasi IG; d. sosialisasi dan pemahaman atas pelindungan IG; e. pemetaan dan inventarisasi potensi produk IG; f. pelatihan dan pendampingan; g. pemantauan, evaluasi, dan pembinaan; h. pelindungan hukum; dan i. fasilitasi pengembangan, pengolahan, dan pemasaran barang dan/atau produk IG. 
maupun pelatihan yang dilakukan secara efisien dan efektif untuk memperoleh hasil yg lebih baik. ${ }^{33}$

Adanya ketentuan pembinaan dan pengawasan IG penting untuk meningkatkan daya saing pelaku usaha, karena Pertama, IG mengidentifikasi sumber atau asal produk. Kedua, IG mengindikasikan kualitas produk dengan menginformasikan konsumen bahwa suatu barang berasal dari daerah atau wilayah yang memberikan kualitas, reputasi, atau karakteristik lainnya yang esensial dapat dikaitkan dengan asal geografisnya. Ketiga, IG dapat mempresentasikan kepentingan bisnis (business interest) karena menjamin keaslian suatu barang yang berkarakteristik dari daerah tertentu. ${ }^{34}$

\section{Implikasi Perlindungan IG Berdasarkan Undang-Undang Nomor 20 Tahun 2016 terhadap Peningkatan Ekonomi Lokal}

International Labour Organization (ILO) menjelaskan pengembangan ekonomi lokal ${ }^{35}$ adalah proses partisipatif yang mendorong kemitraan antara dunia usaha dan pemerintah dan masyarakat pada wilayah tertentu, yang memungkinkan kerjasama dalam perancangan dan pelaksanaan strategi

33 Pembinaan dapat diartikan sebagai upaya memelihara dan membawa suatu keadaan yang seharusnya terjadi atau menjaga keadaan sebagaimana seharusnya. Dalam manajemen perlindungan IG, pembinaan dilakukan dengan maksud agar kegiatan atau program IG yang sedang dilaksanakan selalu sesuai dengan rencana atau tidak menyimpang dari hal yang telah direncanakan. pembinaan dapat ditinjau dari dua sudut pandang, yaitu berasal dari sudut pembaharuan dan berasal dari sudut pengawasan. Pembinaan yang berasal dari sudut pembaharuan yaitu mengubah sesuatu menjadi yang baru dan memiliki nilai-nilai lebih baik bagi kehidupan masa yang akan datang. Sedangkan pembinaan yang berasal dari sudut pengawasan yaitu usaha untuk membuat sesuatu lebih sesuai dengan kebutuhan yang telah direncanakan. Lihat p://rinitarosalinda.blogspot.co.id/2015/10/pembinaan-dan-monitoring.html diakses 28 Desember 2017 pukul 21.00.

34 Wahyu Sasongko, Wahyu,"Indikasi Geografis Studi Tentang Kesiapan Indonesia Memberikan Perlindungan Hukum Terhadap Produk Nasional”, Disertasi Program Doktor Pascasarjana Fakultas Hukum Universitas Indonesia, 2010, hlm 103. Lihat juga Tomy Pasca Rifai, Supra No 4.

35 Pengembangan/pe'ngem $\cdot$ bang $\cdot a n / n=$ proses, cara, perbuatan mengembangkan sedangkan "ekonomi" diartikan sebagai tata perekonomian (suatu Negara), Lihat Kamus Bahasa Indonesia. Menurut Paul A. Samuelson, ekonomi merupakan cara-cara yang dilakukan oleh manusia dan kelompoknya untuk memanfaatkan sumber-sumber yang terbatas untuk memperoleh berbagai komoditi dan mendistribusikannya untuk dikonsumsi oleh masyarakat. Lihat https://carapedia.com/pengertian_definisi ekonomi menurut para ahli_info501.html diakses 14 Desember 2017 pukul 22.20. 
pembangunan secara umum, dengan menggunakan sumber daya lokal dan keuntungan kompetitif dalam konteks global, dengan tujuan akhir menciptakan lapangan pekerjaan yang layak dan merangsang kegiatan ekonomi. ${ }^{36}$ Dalam kaitan dengan pengembangan ekonomi lokal ${ }^{37}$ melalui IG, maka pelaksanaannya tidak hanya hasil (output) berupa nilai ekonomi yang menjadi tujuan tetapi juga prosesnya harus sesuai dengan kebijakan Pemerintah Daerah dalam mewujudkan penghasilan asli daerah dan tingkat kesejahteraan pemilik IG masyarakat yang bersangkutan. Pemangku kepentingan, seperti Pemerintah Daerah, Dunia Industri, Perguruan Tinggi, dan kelompok masyarakat perlu aktif berpartispasi untuk mengelola berdasarkan prinsip menajemen moderen tetapi tetap menggunakan sumber lokal karena dilakukan oleh daerah (lokasi) tertentu.

Dimensi atau batasan pengembangan ekonomi lokal adalah sebagai berikut: 38

(1). Pengertian lokal tidak merujuk pada batasan wilayah administratif tetapi lebih pada peningkatan kandungan komponen lokal maupun optimalisasi pemanfaatan sumberdaya lokal.

(2). Sebagai inisiatif daerah yang dilakukan secara partisipatif.

(3). Menekankan pada pendekatan pengembangan bisnis, bukan pada pendekatan bantuan sosial yang bersifat karikatif.

(4). Bukan merupakan upaya penanggulangan kemiskinan secara langsung.

(5). diarahkan untuk mengisi dan mengoptimalkan kegiatan ekonomi yang dilakukan berdasarkan pengembangan wilayah, pewilayahan komoditas, tata ruang, atau regionalisasi ekonomi.

\footnotetext{
${ }^{36} \underline{\mathrm{http}}: / /$ web.unair.ac.id/admin/file/f 19997 sei13.pdf diakses 15 Desember 2017 pukul 19.00. Selanjutnya, Pengembangan ekonomi lokal menurut pengertian tersebut: berorientasi kepada output dan proses, pelibatan stakeholder harus partisipastif, sifat kelokalan ditunjukkan dari penggunaan sumber daya lokal, Aspek lokasi ditunjukkan bahwa Pengembangan ekonomi lokal dilakukan pada wilayah tertentu. Id.

${ }^{37}$ Ciri utama pengembangan ekonomi lokal adalah titik beratnya pada kebijakan "endogenous development" mendayagunakan potensi sumber daya manusia, institutional dan fisik setempat. Orientasi ini mengarahkan kepada fokus dalam proses pembangunan untuk menciptakan lapangan kerja baru dan merangsang pertumbuhan kegiatan ekonomi. Yulita Indah Prasetiari, Fakultas Ilmu Administrasi Universitas Brawijaya, Strategi Pengembangan Ekonomi Lokal: Implementasi Perencanaan Pembangunan Ekonomi Berbasis Pemberdayaan Di Kabupaten Sidoarjo, hlm 184 tersedia dalam http://download.portalgaruda, diakses 16 Desember 2017 pukul 21.00.

38 Id.
} 
IG memainkan peran kunci dalam pengembangan ekonomi suatu bangsa, dengan memberikan kesempatan kepada produsen untuk secara bersama-sama mempertahankan dan meningkatkan kualitas produknya, melakukan konsolidasi atau bahkan meningkatkan harga di pasar. Selanjutnya, reputasi yang dibangun untuk IG dapat menjadi alat pemasaran yang penting dalam memperkuat posisi produk di pasar sekaligus untuk menembus pasar yang baru. Konsumen bersedia membayar harga produk terkenal tersebut berkat informasi tentang kualitas, asal dan tradisi dari IG, sehingga mengembangkan rasa loyalitas yang kuat. Selain itu, masyarakat setempat dapat mengambil manfaat dari akibat langsung maupun tidak langsung yang dimiliki IG di wilayah tersebut. 39

Berdasarkan hasil dari studi, terdapat penilaian bahwa IG Indonesia telah memiliki hasil positif sejak didaftarkan: 40

- Ada peningkatan signifikan dalam jumlah produsen yang terlibat (misal: Jumlah pengumpul madu Sumbawa bertambah tiga kali lipat dalam 5 tahun).

- Beberapa IG terdaftar telah berhasil memperoleh harga premium (misal: ada kenaikan harga sebesar $40 \%$ dalam 5 tahun untuk madu Sumbawa).

- Volume ekspor juga bertambah (misalnya lebih dari 1 juta ton Kopi Gayo Arabika dalam 5 tahun).

- IG terdaftar telah mengkonsolidasi organisasi, mengumpulkan para pemegang kepentingan, melalui peran penting dari kelompok pengelola IG.

- Peningkatan progresif pada manajemen untuk kualitas produk, melalui sistem ketertelusuran dalam proses pembentukan di beberapa IG .

39 http://www.euind-tcf.com/id/the-economic-benefits-of-indonesian-gis/ diakses 2 Januari 2018 pukul 21.00. selanjutnya Indonesia telah mengembangkan konsep "IG" sejak tahun 2001, dengan UU No 15 Tahun 2001 Tentang Merek, dan PP No. 52 Tahun 2007 Tentang IG. Selanjutnya melalui UU No 15 Tahun 2001 diubah melalui UU No 20 Tahun 2016 Tentang Merek dan IG yang mengatur IG lebih komprehensif untuk pengembangan lebih lanjut sistem IG. Sejak perkembangan sistem sui generis tersebut, hingga kini lebih dari 35 produk terkenal Indonesia telah mengikuti rute IG dan telah terdaftar di Indonesia oleh otoritas yang berwenang, yaitu Ditjen KI. Id.

${ }^{40} \mathrm{Id}$. 
- Pemegang kepentingan dari kelompok IG telah semakin menyadari tentang pentingnya memiliki sistem kontrol untuk memantau kualitas produk.

- Sistem ketertelusuran tersebut telah memberikan kontribusi positif untuk meningkatkan koordinasi dalam rantai pasokan, membangun database yang dikelola dan diperbarui oleh kelompok IG.

- Beberapa IG yang terdaftar di Indonesia telah berperan aktif untuk memperkuat reputasi dan pengakuan terhadap pelanggan dan konsumen (misalnya melalui pameran Lada Putih Muntok oleh pemerintah daerah)

- Para pemegang kepentingan IG terdaftar telah semakin memahami pentingnya keberlanjutan produk dan perlindungannya.

Beberapa daerah yang merupakan potensi IG Indonesia adalah: Aceh (Kopi Arabika Gayo ${ }^{41}$ dan Nilam Aceh ${ }^{42}$ ); Sumatra Utara (Kopi Arabika Lintong/43 Mandailing, Kopi Arabika Sidikalang, Kopi Robusta Sidikalang, Kemenyan, dan Tembakau Deli); Jambi44 (Kayu Manis Kerinci/Kurintci Cassiavera); Lampung ${ }^{45}$ (Kopi Robusta lampung dan Lada Hitam Lampung); Bangka(Lada Putih Muntok); Jawa Barat (Teh,46 Ubi Cilembu ${ }^{47}$, Nanas Subang48, Beras Pandanwangi

${ }^{41}$ http://www.hinamagazine.com/index.php/2008/12/31/di-tengah-krisis-pasar-kopi-gayomasih-cerah diakses 16 Desember 2017 pukul 19.00 .

42 Buletin TRO XV No. 2, 2004.

${ }^{43}$ http://www.sca-indo.org/id diakses 17 Desember 2017 pukul 21.00.

${ }^{44}$ http://bankdata.depkes.go.id/kompas/Kabupaten\%20Kerinci.pdf diakses 19 Desember 2017 pukul 22.00.

$45 \mathrm{http}: / /$ www.radarlamsel.com diakses 20 Desember 2017 pukul 19.30.

46 Pada tahun 2002 nilai ekspor teh Indonesia mencapai 103,4 juta dollar AS, dengan volume ekspor 94.700 ton untuk teh hitam dan 5.500 ton teh hijau. Tahun 1993 nilai ekspor teh Indonesia ini mencapai 155,7 juta dollar dengan volume ekspor 123.926 ton. Pada 1998 nilai ekspor teh Indonesia menurun menjadi 113,2 juta dollar dengan volume 67.219 ton. Data ini menggambarkan bahwa penerimaan devisa dari ekspor teh Indonesia ternyata menurun dari 1993 dan 1998. Yang paling mengkhawatirkan adalah data 1998-2002, di mana volume ekspor meningkat 33.000 ton, tetapi pendapatan menurun 9,8 juta dollar atau Rp 83,3 miliar dalam empat tahun. Lihat http://www2.kompas.com/kompas-cetak/0404/10/ekonomi/960895.htm diakses 21 Desember 2017 pukul 20.00.

${ }^{47}$ http://www.gatra.com/artikel.php lihat juga http://indrakh.wordpress.com/2007/04/03/cilembu-sentra-ubi-si-madu diakses 22 Desember 2017 pukul 19.45.

$48 \mathrm{http}: / /$ www.indosiar.com/news/kisi-kisi/63474 /usaha-perkebunan-nanas-madu diakses 22 Desember 2017 pukul 21.00. 
Cianjur); Jawa Tengah (Telur Asin Brebes ${ }^{49}$, Java Tea, Kopi Robusta Temanggung, Durian Petruk Jepara) ${ }^{50}$; Jawa Timur (Tembakau Besuki dan Aggur Besuki).

Potensi ekonomi IG di daerah-daerah tersebut bernilai tinggi, misalnya Ekspor kopi Sumut menurut data AEKI Sumut telah mencapai 71,68 juta dolar AS dari volume ekspor biji dan bubuk kopi sebanyak 21.969 ton. Dari jumlah ini kopi jenis arabika menjadi penyumbang terbesar yakni 65,07 juta dolar AS dari volume ekspor sebanyak 19.137 ton. ${ }^{51}$ Kayu manis Jambi diperkirakan dalam setahun mencapai Rp 53,75 milyar. ${ }^{52}$ Kopi Robusta lampung selama 2007 yang mencapai 183.070 ton itu menghasilkan devisa sekitar 301,643 juta dolar AS. 53

Berdasarkan potensi di berbagai daerah tersebut, maka IG memiliki nilai ekonomi tinggi sehingga menjadi sarana untuk pengembangan ekonomi lokal, tetapi memerlukan komitmen dari para pemangku kepentingan (stake holder) dalam pengelolaannya serta dukungan dari pemerintah daerah dan pusat. Hal ini sejalan dengan Teori Public Benefit, bahwa Kekayaan Intelektual (IG) merupakan suatu alat untuk meraih dan mengembangkan ekonomi. ${ }^{54}$ Inti teori ini mengakui bahwa perlindungan atas kekayaan intelektual adalah suatu alat dari pembangunan ekonomi yaitu keseluruhan tujuan dibangunnya suatu sistem perlindungan atas sistem perlindungan atas kekayaan intelektual yang efektif. 55

\footnotetext{
${ }^{49}$ http://www.suaramerdeka.com/harian/0408/19/eko06.htm diakses 22 Desember 2017 pukul 21.00.

${ }^{50}$ Flona Edisi 72/V Februari 2009

51 http://humbang.com/internasional-doyan-kopi-arabika-sumut/ diakses 23 Desember 2017 pukul 20.00.

52 http://bankdata.depkes.go.id/kompas/Kabupaten\%20Kerinci.pdf diakses 23 Desember 2017 pukul 21.00.

53 http://www.radarlamsel.com diakses 23 Desember 2017 pukul 22.00.

${ }^{54}$ Nico Kansil, Perlindungan Hukum terhadap KI, Makalah pada Seminar Nasional KI, UNDIP Semarang, tanggal 27 April 1993. Lihat juga Ranti Fauza Mayana, Perlindungan Desain Industri di Indonesia dalam Era Perdagangan Bebas, Grasindo, Jakarta, 2004, hlm 89-90.

${ }^{55}$ http://digilib.unila.ac.id/10350/10/BAB\%20II.pdf diakses 31 Maret 2018 pukul 02.00.
} 


\section{Peningkatkan potensi ekonomi lokal dari masyarakat (dan Pemda) yang mendaftarkan indikasi geografis di Indonesia}

Berdasarkan data Sosio-Ekonomis dari negara-negara Eropa, produkproduk IG dapat memberikan keuntungan besar bagi perekonomian negara tersebut. Penjualan wine di Perancis naik sekitar 230 \% dari penjualannya ke negara lain. Penjualan keju naik antara 158-203\%. ${ }^{56}$ Penjualan jeruk Florida asli dari negara bagian di Amerika Serikat, Florida yang dikenal secara luas di dunia dengan kekhasan rasanya, dapat menyumbangkan 9 juta US Dollar, membuka sekitar 80.000 lapangan kerja baru dan mengekspansi 230, 670 hektar lahan. ${ }^{57}$ Apabila dibandingkan dengan potensi IG di Indonesia, banyak potensi yang dapat dimanfaatkan untuk bersaing di dunia regional maupun internasional. Produkproduk dimaksud, misalnya Ubi Cilembu, Wajit Cililin, Batik Trusmi (Cirebon), Batik Pekalongan, Batik Solo, Jenang Kudus, Seni Topeng Cirebon, Batik Yogyakarta, Keramik Kasongan Yogyakarta, Apel Malang, Brem Bali, Songket Silungkang (Sumatera Barat), Kain Songket Palembang, Ukiran Toraja, dan Kain Sasirangan (Kalimantan Selatan). ${ }^{58}$ Dari produk kopi, setidaknya ada sejumlah kopi yang memiliki cita rasa yang khas, yaitu dari jenis kopi Arabica: kopi Lintong (Batak), kopi Mandheling (Batak), Kopi Gayo, kopi Toraja, kopi Kalosi, kopi Kintamani Bali, kopi Bajawa, kopi Luwak. Dari jenis Robusta: kopi Pagaralam, kopi Lampung, kopi Jawa Dampit, kopi Robusta Flores. ${ }^{59}$

\footnotetext{
56 John A. Clarke, The Public Policy Objectives of Geographical Indications, Worldwide Symposium on Geographical Indications, Lima 22-24 Juni 2011, hlm 5 Sebagaimana dikutip oleh Indra Rahmatullah, Supra no.4.

57 Keck, Ken, Florida Orange Juice Healthy, Pure and Simple, Worldwide Symposium on Geographical Indications, Lima 22-24 Juni 2011 Sebagaimana dikutip oleh Indra Rahmatullah.

58 Sudarmanto, Produk Kategori Indikasi Geografis Potensi Kekayaan Intelektual Masyarakat Indonesia, Simposium Nasional Kepentingan Negara Berkembang Terhadap Hak Atas Indikasi Geografis, Sumber Daya Genetika dan Pengetahuan Tradisional, Lembaga Pengkajian Hukum Internasional FH Universitas Indonesia bekerjasama dengan Ditjen Hak Kekayaan Intelektual, Depok tahun 2005, hlm 114 sebagaimana dikutip oleh Indra Rahmatullah, Supra no 4.

59 Surip Mawardi, "Establishment of Geographical Indication Protection System in Indonesia, Case in Coffee," Worldwide Symposium on Geographical Indications jointly orginized by the World Intellectual Property Organization (WIPO) and the Patent Office of the Republic of Bulgaria, Sofia, June 10 - 12, 2009 hlm 3 dikutip oleh Indra Rahmatullah.
} 
Sampai tahun Februari 2016, IG Indonesia yang telah terdaftar pada Ditjen KI berjumlah 35, antara lain: Kopi Arabika Kintamani Bali oleh MPIG (Masyarakat Perlindungan IG) IDG 000000001 (5 Desember 2008), Mebel Ukir Jepara oleh Jepara IG ID G 000000003 (28 April 2010), Lada Putih Muntok oleh Badan Pengelola, Pengembangan dan Pemasaran Lada (BP3L) Provinsi Kepulauan Bangka Belitung ID G 000000004 (28 April 2010), Kopi Arabika Gayo Masyarakat Perlindungan Kopi Gayo (MPKG) ID G 000000005 (28 April 2010), Susu Kuda Asosiasi Pengembangan Susu Sumbawa Kuda Sumbawa ID G 000000010 (15 Desember 2011), Madu Sumbawa oleh Jaringan Madu Hutan Sumbawa ID G 000000012 (15 Desember2011), Kopi Arabika Flores Bajawa oleh Masyarakat Perlindungan Flores Bajawa IG (MPIG) Kopi ID G 000000014 (28 Maret 2012), Ubi Cilembu Sumedang oleh Asosiasi Agrobisnis Ubi Cilembu (ASAGUCI) ID G 000000019 (24 April 2013), Minyak Nilam Aceh oleh Forum Masyarakat Perlindungan Nilam Aceh (FMPNA) ID G 000000021(10 September 2013), Beras Pandanwangi oleh Masyarakat Pelestari Padi Pandanwangi Cianjur (MP3C) ID G 000000034 (16 Oktober 2015), Teh Java Preanger oleh Masyarakat Perlindungan Indikasi Geografis (MPIG) Teh Java Preanger ID G 0000000387 (23 Desember 2015), Garam Amed Bali Masyarakat Perlindungan IG (MPIG) Garam Amed Bali ID G 000000038 (23 Desember 2015). ${ }^{60}$

Keuntungan dari potensi yang dimiliki, dapat terjadi jika negara-negara (termasuk Indonesia) dapat melindungi produk-produk khasnya dengan sistem perlindungan IG. Dari titik ini, perlindungan IG secara internasional sangat diperlukan. ${ }^{61}$ Ketua Tim Ahli IG, Surip Mawardi mengakui tantangan terberat

\footnotetext{
${ }^{60}$ Candra Irawan, Protection of Traditional Knowledge: A Perspective on Intellectual Property Law in Indonesia, Journal of World Intellectual Property Right, John Wiley and Son Ltd, March 2017, Volume 20, Issue 1-2, HIm 63, tersedia dalam DGIP, Indikasi Geografis Terdaftar, http://www.dgip.go.id/, diakses 28 Desember 2017pukul 19.00 Lihat juga Candra Irawan, Pendaftaran Indikasi Geografis Sebagai Instrumen Perlindungan Hukum Dan P eningkatan Daya Saing Produk Daerah Di Indonesia tersedia dalam https://media.neliti.com/media/publications/174023-ID-pendaftaran-indikasi-geografissebagai-i.pdf diakses 28 Desember 2017 pukul 20.00.

${ }^{61}$ Dengan perlindungan secara internasional, beberapa manfaat dapat diambil, yaitu a). IG dapat digunakan sebagai strategi pemasaran produk pada perdagangan dalam dan luar negeri, b).
} 
adalah penguatan organisasi masyarakat sebagai produsen barang yang dilindungi rezim IG. Sebab, proses pendaftaran produk IG tidak tergantung pada individu, melainkan pada masyarakat. Perlindungan IG, perlu dukungan bukan hanya dari produsen, tetapi juga dari Pemerintah sehingga dukungan politik yang minimal dari pemerintah dapat menjadi hambatan yang mengakibatkan Indonesia akan ketinggalan oleh India dan Thailand. 62 Oleh karena itu upaya pemerintah untuk mendorong masyarakat (pemda) agar mendaftarkan IG yang dimiliknya menjadi faktor yang penting baik dilihat secara nasional maupun internasional.

Dari perspektif nasional, pengaturan IG harus memadai agar mendukung upaya pengembangan ekonomi lokal bahkan dapat bersaing secara global, karena substansi pengaturan IG yang komprehensif berakibat pada adanya kepastian hukum bagi pemegang hak (masyarakat lokal), sehingga akan mendorong timbulnya kreasi-kreasi IG yang bernilai ekonomi tinggi. Dengan demikian, pengaturan IG yang komprehensif berkorelasi positif dengan pengembangan ekonomi lokal. Sedangkan dari perspektif internasional, pendaftaran merupakan sarana untuk melindungi potensi ekonomi IG Indonesia terhadap klaim negara lain.

Kepastian hukum tidak hanya berkisar soal substansi hukumnya tetapi juga menyangkut proses terjadinya Nomorrma hukum tersebut. Dalam kaitan ini, Kelsen mengatakan bahwa sistem hukum adalah suatu sistem Nomorrma, 63 dengan menekankan pada pernyataan "bahwa suatu sistem Nomorrma dikatakan valid jika diperoleh dari Nomorrma yang lebih tinggi diatasnya, yang selanjutnya sampai pada tingkat Nomorrma tersebut tidak dapat diperoleh dari Nomorrma

Memberikan nilai tambah terhadap produk dan meningkatkan kesejahteraan pembuatnya, c). Meningkatkan reputasi produk IG dalam perdagangan internasional, d). Persamaan perlakuan sebagai akibat promosi dari luar negeri, dan e). Perlindungan IG sebagai salah satu alat untuk menghindari persaingan curang.

62 Misalnya pendaftaran Kopi Kintamani dilakukan Masyarakat Perlindungan IG (MPIG), Minyak Nilam Aceh oleh Forum Masyarakat Perlindungan Nilam Aceh (FMPNA), Lihat http://www.hukumonline.com, Perlindungan Produk Indikasi Geografis Indonesia Masih Tertinggal, diakses 29 Desember 2017 pukul 21.00.

${ }^{63}$ Hans Kelsen, Teori Umum Tentang Hukum dan Negara, Nusa Media, Bandung, 2008, hlm. 159. Lihat juga Jimmy Yansen, Penerapan Norma Hukum Dalam Sistem Hukum Indonesia "Penerapan Norma Hukum di Lembaga Peradilan", Makalah, tanpa tahun. 
lain yang lebih tinggi, ini yang disebut sebagai Nomorrma dasar. ${ }^{64}$ Dalam kaitan dengan IG, lahirnya Undang-Undang Nomor 20 Tahun 2016 sejalan dengan Nomorrma dasar (Undang-Undang Dasar 1945), khususnya Pasal 28 C “ (1) Setiap orang berhak mengembangkan diri melalui pemenuhan kebutuhan dasarnya, berhak mendapat pendidikan dan memperoleh manfaat dari ilmu pengetahuan dan tekNomorlogi, seni dan budaya, demi meningkatkan kualitas hidupnya dan demi kesejahteraan umat manusia. (2) Setiap orang berhak untuk memajukan dirinya dalam memperjuangkan haknya secara kolektif untuk membangun masyarakat, bangsa dan negaranya.” Selanjutnya Pasal 28 I Ayat (3)“Identitas budaya dan hak masyarakat tradisional dihormati selaras dengan perkembangan zaman dan peradaban." Ketentuan Nomorrma konstitusi tersebut berasal dari Norma dasar (grundNomorrm) yaitu Pancasila (sila ke 2 dan ke 5).

Efektivitas Undang-Undang Nomor 20 Tahun 2016, khususnya ketentuan yang mengatur IG dapat menjadi salah satu faktor pengembangan ekonomi lokal tidak hanya ditentukan oleh substansi (isi) hukumnya tetapi juga struktur hukum (penegak hukum) dan budaya hukum (masyarakat) sebagaimana dikemukakan oleh Lawrence W Friedman, ${ }^{65}$ serta memerlukan dukungan semua stakeholder terkait termasuk dukungan politik dari pemerintah.66 Kebutuhan dan tuntutan mengenai pengaturan IG dalam sistem hukum nasional yang dipengaruhi oleh perkembangan regulasi internasional merupakan contoh dari tantangan pembangunan hukum nasional abad ke-21. Seperti yang dikemukakan oleh Sunaryati HartoNomor, tantangan itu menyangkut “... sistem hukum yang masih beraneka-ragam dan berlapis-lapis, dan semakin pluralistis dan saling berbentrokan kepentingannya." 67

\footnotetext{
64 Id, hlm 161.

65 Selengkapnya Pembahasan tersebut lihat Lawrence W Friedman Sistem Hukum, Perspektif Ilmu Sosial (The Legal System ; A Social Science Perspective), Nusa Media, Bandung, 2009.

${ }^{66}$ Hukumonline, Supra no 57.

${ }^{67}$ Sunaryati Hartono, Supra no 11, hlm. 259.
} 


\section{Penutup}

\section{Kesimpulan}

1. Undang-Undang Nomor 20 Tahun 2016 sebagai implementasi dari ketentuan internasional (terutama TRIPs) lebih memadai dibandingkan dengan peraturan sebelumnya yaitu Undang-Undang Nomor 15 Tahun 2001 sehingga lebih memberikan kepastian hukum.

2. IG di beberapa daerah di Indonesia memiliki nilai ekonomi tinggi sehingga berpotensi sebagai pengembangan ekonomi lokal.

3. Persyaratan pendaftaran IG menurut Undang-Undang Nomor 20 Tahun 2016 memiliki urgensi baik secara nasional maupun internasional bagi potensi ekonomi lokal.

\section{Saran}

1. Undang-Undang Nomor 20 Tahun 2016 perlu ditindaklanjuti dengan peraturan Pelaksanaannya baik Peraturan Pemerintah mapun Peraturan Menteri.

2. Untuk mengembangkan potensi IG sebagai pengembangan ekonomi lokal perlu dilakukan tindakan strategis antara lain, Pemerintah pusat dan daerah membuat perencanaan yang integral, mengidentifikasi dan mengembangkan potensi IG sesuai kearifan lokal, serta mengalokasikan APBN/APBD sesuai dengan potensi IG di masing-masing daerah.

3. Perlu peningkatan kesadaran hukum bagi masyarakat melalui penyuluhan hukum tentang pentingnya pendaftarkan IG yang memiliki potensi ekonomi tinggi. 


\section{Daftar Pustaka}

Buku:

Andy Nomororsaman Sommeng dan Agung Damar Sasongko, Indikasi Geografis: Sebuah Pengantar, Jakarta: Direktorat Jenderal HKI (DJHKI), 2008.

Eddy Damian, dkk. Hak Kekayaan Intelektual Suatu Pengantar, Bandung: Alumni, 2002.

Hans Kelsen, Teori Umum Tentang Hukum dan Negara, Nusa Media, , Bandung, 2008.

Lawrence W Friedman, Sistem Hukum, Perspektif Ilmu Sosial (The Legal System: A Social Science Perspective), Nusa Media, Bandung, 2009.

Ranti Fauza Mayana, Perlindungan Desain Industri di Indonesia dalam Era Perdagangan Bebas, Grasindo, Jakarta, 2004.

Sudaryat et al, Hak Kekayaan Intelektual, Oase Media, Bandung, 2010.

OK. Saidin, Aspek Hukum Hak Kekayaan Intelektual (Intellectual Property Rights,) Raja Grafindo, Jakarta, 2004.

I Gede Agus Kurniawan, Pengaturan Penghentian Pemakaian Indikasi Geografis Pada Merek Terdaftar Oleh Pihak Lain Yang Tidak Berhak (Studi Komparatif Beberapa Negara), Program Studi Ilmu Hukum Pasca Sarjana Universitas Udayana, Denpasar, 2013.

Jimmy Yansen, Penerapan Nomorrma Hukum Dalam Sistem Hukum Indonesia "Penerapan Nomorrma Hukum di Lembaga Peradilan", Makalah, tanpa tahun.

Ken Keck, "Florida Orange Juice Healthy, Pure and Simple", Worldwide Symposium on Geographical Indications, Lima 22-24 Juni 2011.

Mahkamah Agung RI, GATT, TRIPS Dan Kekayaan Intelektual, 1998.

Nico Kansil, Perlindungan Hukum terhadap KI, Makalah pada Seminar Nasional KI, UNDIP Semarang, tanggal 27 April 1993.

Sudarmanto, Produk Kategori Indikasi Geografis Potensi Kekayaan Intelektual Masyarakat Indonesia, Simposium Nasional Kepentingan Negara Berkembang Terhadap Hak Atas Indikasi Geografis, Sumber Daya Genetika dan Pengetahuan Tradisional, Lembaga Pengkajian Hukum Internasional FH Universitas Indonesia bekerjasama dengan Ditjen Hak Kekayaan Intelektual, Depok tahun 2005.

Surip Mawardi, "Establishment of Geographical Indication Protection System in Indonesia, Case in Coffee," Worldwide Symposium on Geographical Indications jointly orginized by the World Intellectual Property Organization (WIPO) and the Patent Office of the Republic of Bulgaria, Sofia, June 10 - 12, 2009.

Tomy Pasca Rifai, Kesiapan Undang-Undang Nomormor 20 Tahun 2016 Tentang Merek Dan Indikasi Geografis Dalam Menghadapi Masyarakat Ekonomi ASEAN, Faculty of Law, Lampung University, Jurnal Fiat Justitia, volume 10 issue 4, October-December 2016. 
Wahyu Sasongko,"Indikasi Geografis Studi Tentang Kesiapan Indonesia Memberikan Perlindungan Hukum Terhadap Produk Nasional", Disertasi Program Doktor Pascasarjana Fakultas Hukum Universitas Indonesia, 2010.

\section{Peraturan Perundangan:}

Republik Indonesia, Undang-Undang Dasar 1945

Republik Indonesia, Undang-Undang Nomormor 15 Tahun 2001 Tentang Merek, LN RI Tahun 2001 Nomor. 110.

Republik Indonesia, Undang-Undang Nomormor 20 Tahun 2016 Tentang Merek dan Indikasi Geografis, LN RI Tahun 2016 Nomor. 252.

Paris Convention for the Protection of Industrial Property atau Agreement Establishing the World Trade Organization, 1883.

Lisbon Agreement for the Protection of Appellations of Origin and their International Registrationn of October 31, 1958, as revised at Stockholm on July 14, 1967, and as amended on September 28, 1979.

Madrid Agreement Concerning The International Registration of Marks, 1981.

Trade Related Aspect of Intellectual Property Rights/TRIPs-WTO.

Jurnal:

Aristeus, Syprianus, "Peluang Industri dan Perdagangan Indonesia Dalam Pelaksanaan Masyarakat Ekonomi ASEAN (Industry and Trade Opportunity of Indonesia on ASEAN Eco Nomormic Community), Media Pembinaan Hukum Nasional, Jurnal Rechtsvinding 2014, 3(2).

Buletin TRO XV Nomor. 2, 2004 .

Christophe Bellmann, Graham Dutfield \& Melendez-Ortiz, Trading in KNomorwledge: Development Perspectives on TRIPS, Trade and Sustainability, International Centre for Trade and Sustainable Development (ICTSD), Earthscan, London, 2003.

Clarke John A., "The Public Policy Objectives of Geographical Indications", Worldwide Symposium on Geographical Indications, Lima 22-24 Juni 2011.

Candra Irawan, Protection of Traditional Knomorwledge: A Perspective on Intellectual Property Law in Indonesia, Journal of World Intellectual Property Right, John Wiley and Son Ltd, March 2017, Volume 20, Issue 12,tersedia dalam DGIP, Indikasi Geografis Terdaftar, http://www.dgip.go.id/, diakses 28 Desember 2017 pukul 19.00.

Flona Edisi 72/V Februari 2009.

Sunaryati HartoNomor, Membangun Budaya Hukum Pancasila sebagai Bagian dari Sistem Hukum Nasional Indonesia di Abad 21, Jurnal Veritas et Justitia Edisi 1 Vo. 2, Desember 2015. 


\section{Internet:}

Brian Prastyo, http://staff.blog.ui.ac.id/brian.amy/2008/04/09/merek-danindikasi-geografis/ diakses 26 Desember 2017 pukul 20.00.

Candra Irawan, Pendaftaran Indikasi Geografis Sebagai Instrumen Perlindungan Hukum dan Peningkatan Daya Saing Produk Daerah Di Indonesia tersedia dalam https://media.neliti.com/media/publications/174023-IDpendaftaran-indikasi-geografis-sebagai-i.pdf diakses 28 Desember 2017 pukul 20.00.

Indra Rahmatullah, Perlindungan Indikasi Geografis Dalam Hak Kekayaan Intelektual (HKI) Melalui Ratifikasi Perjanjian Lisabon, wordpress.com/2013/10/25/perlindungan-indikasi-geografis-dalamhakkekayaan-in-telektual-hki-melalui-ratifikasi-perjanjian-lisabon/ diakses tanggal 1 Desember 2017 pukul 21.00.

Hukum online, Perlindungan Produk Indikasi Geografis Indonesia Masih Tertinggal, http://www.hukumonline.com, diakses 29 Desember 2017 pukul 21.00.

https://carapedia.com/pengertian definisi ekonomi menurut para ahli info501. html diakses 14 Desember 2017 pukul 22.20.

http://digilib.unila.ac.id/10350/10/BAB\%20II.pdf diakses 31 Maret 2018 pukul 02.00 .

http://indrakh.wordpress.com/2007/04/03/cilembu-sentra-ubi-si-madu diakses 22 Desember 2017 pukul 19.45.

https://prasetya.ub.ac.id/berita/Melindungi-HAKI-Produk-Lokal-denganImplementasi-Indikasi-Geografis-1661-id.html diaskes 13 Desember 2017 pukul 21.00.

http://web.unair.ac.id/admin/file/f 19997 sei13.pdf diakses 15 Desember 2017 pukul 19.00.

http://www.euind-tcf.com/id/the-ecoNomormic-benefits-of-indonesian-gis/ diakses 2 Januari 2018 pukul 21.00.

http://www.hinamagazine.com/index.php/2008/12/31/di-tengah-krisis-pasarkopi-gayo-masih-cerah diakses 16 Desember 2017 pukul 19.00.

http://www.sca-indo.org/id diakses 17 Desember 2017 pukul 21.00.

http://bankdata.depkes.go.id/kompas/Kabupaten\%20Kerinci.pdf diakses 19 Desember 2017 pukul 22.00.

http://www.radarlamsel.com diakses 20 Desember 2017 pukul 19.30.

http://www2.kompas.com/kompas-cetak/0404/10/ekonomi/960895.htm diakses 21 Desember 2017 pukul 20.00.

http://www.indosiar.com/news/kisi-kisi/63474 /usaha-perkebunan-nanasmadu diakses 22 Desember 2017 pukul 21.00.

http://www.suaramerdeka.com/harian/0408/19/eko06.htm diakses 22 Desember 2017 pukul 21.00.

http://humbang.com/internasional-doyan-kopi-arabika-sumut/ diakses 23 Desember 2017 pukul 20.00. 
http://bankdata.depkes.go.id/kompas/Kabupaten\%20Kerinci.pdf diakses 23 Desember 2017 pukul 21.00.

http://www.radarlamsel.com diakses 23 Desember 2017 pukul 22.00.

http://www.hukumonline.com/klinik/detail/lt4fd1bd073c3a6/indikasi-geografis diakses 26 Desember 2017 pukul 21.00 .

Puji Tri Nuzzuli, Pendaftaran Indikasi Geografis Atas Barang-Barang Hasil Pertanian/Perkebunan Di Aceh teraedia dalam https://media.neliti.com/media/publications/14028-ID-pendaftaranindikasi-geografis-atas-barang-barang-hasil-pertanianperkebunan-dia.pdf diaskes 13 Desember 2017 pukul 22.00 .

p://rinitarosalinda.blogspot.co.id/2015/10/pembinaan-dan-monitoring.html diakses 28 Desember 2017 pukul 21.00.

Saky SeptioNomor, Perlindungan Indikasi Geografis dan Potensi Indikasi Geografis Indonesia tersedia dalam http://kemal-assegaf.blogspot.co.id/2011/12/ indikasi-geografi.html diakses 26 Desember 2017 pukul 21.00.

Yulita Indah Prasetiari, Fakultas Ilmu Administrasi Universitas Brawijaya, Strategi Pengembangan Ekonomi Lokal: Implementasi Perencanaan Pembangunan Ekonomi Berbasis Pemberdayaan Di Kabupaten Sidoarjo, tersedia dalam http://download.portalgaruda. diakses 16 Desember 2017 pukul 21.00.

Wahyu Sasongko, Indikasi Geografis: Rezim HKI Yang Bersifat Sui Generis, Jurnal Media Hukum, 2008 http://download.portalgaruda.org/article. php?article $=98312 \& v a l=648$, diakses 10 Desember 2017 .

WIPO Standing Commiitee on the Law of Trademarks, Industrial Designs and Geographical Indication, SCT/8/4, April 2, 2002 diakses 27 Desember 2017 pukul 22.00. 